\title{
Appendiceal Carcinoma pT1 TNM Finding v7
}

National Cancer Institute

\section{Source}

National Cancer Institute. Appendiceal Carcinoma pT1 TNM Finding v7. NCI Thesaurus.

Code $C 89898$.

Appendiceal carcinoma with tumor invading submucosa. (from AJCC 7th Ed.) 